\title{
ANALISIS PERIBAHASA JEPANG YANG MENGANDUNG UNSUR INU (ANJING)
}

\author{
I. P. Siarta ${ }^{1}$, G. S. Hermawan ${ }^{2}$, N. N. Suartini ${ }^{3}$ \\ ${ }^{123}$ Jurusan Pendidikan Bahasa Jepang, Universitas Pendidikan Ganesha, Singaraja \\ e-mail: siartagen@rocketmail.com, satya.hermawan@undiksha.ac.id, nnsuartini@undiksha.ac.id
}

\begin{abstract}
Abstrak
Penelitian ini bertujuan untuk mendeskripsikan makna peribahasa Jepang yang mengandung unsur inu (anjing). Subjek yang digunakan dalam penelitian ini adalah kamus peribahasa online. Penelitian ini merupakan penelitian deskriptif kualitatif dengan instrumen utama berupa kartu data. Hasil dari penelitian ini yaitu, terdapat 16 peribahasa Jepang. Anjing dalam peribahasa Jepang ada yang bermakna positif dan ada juga yang bermakna negatif. Peribahasa tersebut kemudian diklasifikasikan menjadi 4 bagian berdasarkan isi yaitu (a) jinsei no oshie ya shinri o arawashita (ajaran kehidupan manusia) sebanyak 2 peribahasa, (b) seikatsu no chisiki ya chie o tataite wataru (pengetahuan tentang kehidupan) sebanyak 5 peribahasa, (c) hito o hihan shitari hinikutari shita mono (sindiran) sebanyak 5 peribahasa, dan (d) monogoro no yoosu omoshiroku tatoeta mono (kiasan) sebanyak 4 peribahasa.
\end{abstract}

Kata kunci: Inu, Makna, Peribahasa

\begin{abstract}
要旨
本研究の目的は、「犬」の要素を含んでいる日本の彥の意味を分析することである 調査対象、「犬」の要素を含んでいる日本の彥であり、定性的記述法により分析 した。結果、「犬」の要素を含んでいる日本の彥は16つの中で肯定的な意味や、否 定的な意味を持っている。彥の内容によって 4 つ種類に分類され 1 ）人生の教えや 心理を表した意味が $2 つ 、 2 ）$ 生活の知識や知恵をたたいて渡る彥の意味が $5 つ 、$

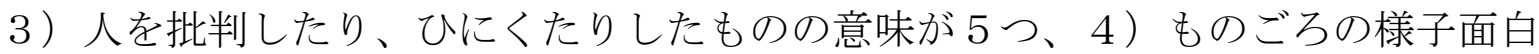
く例えたものの意味が 4 つあることが分かった。
\end{abstract}

キーワード：犬、意味、彥

\section{Pendahuluan}

Bahasa merupakan salah satu bentuk hasil karya budaya yang bersifat kompleks dan aktif (Rahyono, 2015:82). Bahasa dikatakan kompleks karena di dalamnya tersimpan pemikiran-pemikiran kolektif dan semua hal yang dimiliki oleh suatu masyarakat. Bahasa dikatakan aktif karena bahasa terus berubah sesuai dengan perkembangan masyarakat.

Bahasa sebagai alat komunikasi antara anggota masyarakat berwujud simbol bunyi yang dihasilkan oleh alat ucap manusia merupakan alat ekspresi diri sekaligus merupakan alat untuk menunjukkan identitas diri. Sebagai alat ekspresi diri, bahasa biasanya digunakan untuk menyampaikan suatu makna, baik makna yang sebenarnya maupun makna yang tidak sebenarnya atau biasa disebut makna kiasan. Ungkapan yang mengandung makna kiasan biasanya digunakan untuk memperhalus penyampaian sebuah gagasan, pikiran, maupun perasaan kepada lawan bicara.

Peribahasa adalah kata kiasan yang mengandung makna tersembunyi (Wasrie, 2006:3). Peribahasa juga merupakan ungkapan yang terbuat dari kalimat ringkas dan padat yang berisikan perbandingan, perumpamaan, sindiran dan nasihat. Hal ini sesuai dengan pendapat Chaer (2003:297) yang menyatakan bahwa peribahasa terdapat pada semua bahasa yang ada di dunia ini, terutama pada bahasa-bahasa yang penuturnya sudah memiliki kebudayaan yang tinggi. Peribahasa juga dapat dikatakan sebagai bahasa komunikasi yang halus dan sopan dalam menyampaikan suatu pesan, kritik, sindiran, dan nasihat kepada orang lain, mudah dijumpai dalam kehidupan sehari-hari, merupakan bagian dari kebudayaan masyarakat penuturnya, dan sudah ada sejak dini. 
Di Jepang peribahasa disebut dengan kotowaza (諺). Dalam bahasa Jepang, kotowaza didefinisikan sebagai: Furuku kara hitobito ni ii narawasareta kotoba. Kyoukun.fuushi nado no $i \quad$ o $\quad$ guushita tanku ya shuuku (古くから人々に言いならわされたことば。教訓・風刺などの意を寓した短句や秀句) yang artinya kalimat pendek yang berisi seperti pelajaran dan sindiran yang digunakan oleh masyarakat sejak dahulu kala. (Kojien, 1998: 989, dalam Gifari, 2018:1-2).

Peribahasa juga sering kita temui dalam kehidupan sehari-hari yang akan memberikan pembelajaran penting ketika kita dapat memahami arti dari peribahasa tersebut yang disesuaikan dengan realita yang ada. Contoh peribahasa bagai air di daun talas. Jika dilihat dari realita, ketika air berada di atas daun talas, maka gerakan air tersebut tidak bisa diam. Selalu bergerak ke segala arah mengikuti pergerakan daun talas. Oleh karena itu, peribahasa ini digunakan untuk mengungkapkan sifat seseorang yang tidak tetap pendirian dan digunakan untuk memberitahukan orang tersebut tanpa menyakiti perasaan secara langsung.

Pandangan terhadap objek peribahasa di setiap daerah berbeda-beda tergantung letak geografis dan budaya yang berkembang dan mempengaruhi daearah tersebut. Objek yang sering dijadikan perumpamaan dalam peribahasa adalah objek yang sering ditemui dan diibaratkan sesuai realita sifat ataupun keadaan dalam kehidupan. Contohnya tikus, di Indonesia tikus dipandang sebagai hewan yang mencari makanan di tempat yang kotor sehingga dipakai untuk mengumpamakan seorang koruptor yang mencari keuntungan dengan cara tidak baik. Namun, di luar negeri khususnya di Amerika tikus dianggap sebagai hewan lucu yang digemari oleh anak-anak sehingga menginspirasi munculnya tokoh kartun Mickey Mouse. Begitu juga dengan Jepang yang memiliki pandangan tersendiri tentang objek peribahasa yang menggunakan hewan sebagai bahan perumpamaan, khususnya anjing yang memiliki kedekatan melebihi hewan lain dengan masyarakat Jepang.

Anjing dalam bahasa Jepang disebut inu, dan merupakan hewan yang dihormati dan dianggap lambang kesetiaan. Kesetiaan dan pengabdian yang ditunjukkan anjing sangat mirip dengan konsep manusia tentang cinta dan persahabatan. Contoh kesetian inu dapat kita lihat dalam kisah Hachiko. Untuk menghormati kesetiaan Hachiko, di depan Stasiun Shibuya dibangun patung Hachiko dari perunggu dan sampai saat ini kisah Hachiko terus dikenang sebagai lambang kesetiaan oleh masyarakat Jepang (Vijjananda, 2012) .

Analisis makna dan klasifikasi peribahasa Jepang yang mengandung unsur inu menarik untuk diteliti karena didasarkan pada kebiasaan masyarakat Jepang dalam menyampaikan suatu secara tidak langsung atau dengan sindiran. Isi pikiran disampaikan dengan mengibaratkannya dengan sesuatu yang mirip pada sindiran yang ingin disampaikan tersebut. Inu menjadi sebuah pilihan yang tepat sehingga keberadaannya dalam peribahasa Jepang tidak bisa dihilangkan keberadaannya. Oleh karena itu perlu dipahami secara saksama makna dari peribahasa yang mengandung unsur inu supaya dapat memahami maksud sebenarnya dan tidak terjadi salah pahaman dalam pengartian peribahasa saat digunakan sehingga dirasa perlu mendeskripsikan makna peribahasa Jepang yang mengandung kata inu lebih mendalam.

\section{Metode}

Jenis penelitian adalah deskriptif kualitatif. Penelitian deskriptif adalah penelitian untuk menjabarkan, menggambarkan suatu fenomena yang terjadi saat ini dengan menggunakan prosedur ilmiah untuk menjawab masalah secara aktual. Pendekatan ini adalah pendekatan yang paling tepat untuk melakukan analisis yaitu dengan cara mengklasifikasikan, mengumpulkan data, atau menyusun data.

Sumber data yang akan digunakan dalam meneliti makna peribahasa Jepang yang menggunakan kata inu yaitu subjek dalam penelitian ini adalah hewan inu. Sedangkan objek dalam penelitian ini adalah makna dan fungsi yang terkandung dalam peribahasa Jepang yang terbentuk dari kata inu .

Metode yang digunakan untuk mengumpulkan data adalah metode studi kepustakaan. Studi kepustakaan dalam penelitian ini yaitu tahap pengumpulan data literature yang relevan dengan objek penelitian atau masalah yang dikaji. Materi-materi kepustakaan yang dimaksud adalah yang sudah diterbitkan, berupa buku-buku dan laporan penelitian. Buku yang digunakan sebagai sumber data yaitu sumber data online yang dicari dalam laman 
https://proverb-encyclopedia.com. Studi kepustakaan dilakukan untuk memperoleh data primer penelitian.

Metode analisis deskriptif kualitatif digunakan dalam penelitian ini karena data yang didapatkan bukan berupa angka, melainkan kata-kata. Data yang berupa korpus, dianalisis secara deskriptif kualitatif. Data yang diperoleh yang selanjutnya dianalisis adalah makna dan fungsi peribahasa Jepang yang menggunakan kata inu sehingga dapat menjabarkan tahapan-tahapan penelitian sebagai kerangka penelitian yang mengikuti kerangka penelitian yang diujicobakan.

Analisis tahap awal merupakan tahap awal dalam menganalisis.Kegiatan analisis awal merupakan kegiatan membaca, memahami dan mencatat peribahasa Jepang yang menggunakan kata inu. Objek dalam penelitian ini yang dicari korpusnya adalah peribahasa Jepang dengan peribahasa Jepang yang menggunakan kata inu. Korpus yang dimaksud adalah peribahasa Jepang yang menggunakan kata inu.

Analisis tahap akhir ini dilakukan kegiatan penyimpulan atau generalisasi analisis tahap awal dan lanjutan yakni memberikan penjelasan dari masing-masing temuan yang ada dan kemudian dapat ditarik sebuah kesimpulan sementara hasil penelitian.

Analisis tahap lanjutan yang merupakan kegiatan lanjutan dari analisis tahap awal. Pada tahap ini dilakukan pengelompokkan, pengklasifikasian korpus yang telah ditemui dan dimasukkan ke dalam korpus data. Korpus data yang telah dibuat tersebut adalah peribahasa Jepang yang menggunakan kata inu.

\section{Hasil dan Pembahasan}

Berdasarkan sumber data, diperoleh sebanyak 16 peribahasa Jepang yang mengandung unsur inu yang dianalisis berdasarkan makna denotasi, makna konotasi, dan situasi penerapan dalam kehidupan sehari-hari. 16 peribahasa Jepang tersebut juga diklasifikasikan berdasarkan isi.

Pertama, Kai inu ni te o kamareru (飼い犬に手を噛まれる) yang artinya anjing yang menggigit tangan tuannya. Dilihat dari makna denotasi, peribahasa kai inu ni te o kamareru (飼い犬に手を噛まれる) ini terbentuk dari kata kai inu (飼い犬) yang memiliki arti anjing peliharaan, kata te (手) yang memiliki arti tangan dan kata kamu (噛む) yang berarti tertangkap atau dalam konteks peribahasa ini dapat juga disebut sebagai digigit. Dapat dipahami bahwa menurut kata pembentuknya peribahasa ini memiliki makna denotasi anjing yang menggigit tangan tuannya. Alasan pemilihan anjing sebagai makna denotasi disini karena anjing dikenal sebagai hewan peliharaan yang dianngap memiliki kedekatan khusus sehingga seringkali dianggap sahabat manusia. Selanjutnya, dilihat dari segi konotasi peribahasa kai inu ni te o kamareru (飼い犬に手を噛まれる) memiliki makna orang yang tidak tahu balas budi. Di Jepang anjing dianggap sebagai simbol kesetiaan. Oleh karena itu, anjing yang mengigit majikannya tentu saja dianggap sebagai sebuah penggambaran orang yang tidak tahu balas budi, orang yang sudah diberikan kepercayaan justru berhianat dan melupakan semua kebaikan yang telah diberikan. Situasi penerapan peribahasa kai inu ni te o kamareru (飼い犬に手を噛まれる) ini biasanya diungkapkan saat situasi ketika seorang yang merasa dikhianati oleh orang lain yang dipercayainya. Orang yang telah diberikan segalanya dan beranggapan orang tersebut akan setia padanya justru berkhianat dan melupakan segala kebaikan yang pernah diterima dan menggambarkan orang yang tidak tahu balas budi.

Kedua, Inu no tooboe (犬の遠吠え) yang artinya anjing melolong. Dilihat dari makna denotasi, peribahasa inu no tooboe (犬の遠) ini terbentuk dari kata inu (犬) memiliki arti anjing, kata tooi (遠) yang memiliki arti jauh dan kata hoeru (吠える) memiliki arti melolong. Dapat dipahami dari kata pembentuknya peribahasa ini memiliki makna anjing melolong. Pemilihan penggunaan kata anjing pada makna denotasi ini karena saat anjing yang melolong pada umumnya merupakan bentuk ekspresi ketakutan yang dimiliki anjing tersebut untuk menjaga jarak dan bersembunyi dari musuh agar tidak terjadi pertarungan fisik langsung. Selanjutnya, dari segi konotasi peribahasa inu no tooboe (犬の遠吠え) bermakna orang yang tidak berdaya. Di Jepang anjing dianggap hewan yang agresif dan memiliki gigitan yang ditakuti sehingga seringkali diajak berburu karena kekuatannya dalam melawan hewan buruan. Tetapi ketika anjing hanya bisa melolong maka akan dianggap 
menggambarkan seseorang yang sudah tidak berdaya dan hanya mampu bicara untuk menutupi kekurangannya. Situasi penerapan peribahasa inu no tooboe (犬の遠吠え) ini biasanya diungkapkan untuk menyampaikan kritikan dan sindiran tentang orang yang sudah tidak berdaya yang hanya bisa berkata buruk dibelakang untuk menutupi kekuranganya. Peribahasa ini dipakai untuk menyampaikan bahwa kebiasaan tersebut merupakan kebiasaan buruk yang hanya mencerminkan ketidakberdayaan dan iri hati berlebihan yang tidak baik.

Ketiga, Inu mo arukeba, bou ni ataru (犬も歩けば、棒にあたる) yang artinya anjing pun saat berjalan bisa terkena pukulan tongkat. Dilihat dari makna denotasi, peribahasa inu mo arukeba, bou ni ataru (犬も歩けば、棒にあたる) ini terbentuk dari kata inu (犬) yang memiliki arti anjing, kata aruku (歩く) yang memiliki arti berjalan, kata bou (棒) yang memiliki arti tongkat dan kata ataru (当たる) yang memiliki arti dipukul / terkena pukulan / menang undian. Dapat dipahami bahwa menurut kata pembentuknya peribahasa ini memiliki makna denotasi anjing yang berjalan pun bisa terkena pukulan tongkat. Penggunaan kata anjing pada makna denotasi ini karena anjing yang dianggap mampu mengandalkan naluri dan indra yang tajam untuk memprediksi aman tidaknya keadaan di sekitar. Selanjutnya, dari segi konotasi peribahasa inu mo arukeba, bou ni ataru (犬も歩けば、棒にあたる) ini memiliki dua arti yaitu mendapatkan bencana yang tidak terduga dan yang kedua memiliki makna kalau berusaha pasti akan berhasil. Dalam konotasi peribahasa ini umumnya diartikan sebagai orang yang mendapat bencana tidak diduga. Situasi penerapan peribahasa inu mo arukeba, bou ni ataru (犬も歩けば、棒にあたる) ini seringkali dipakai untuk menggungkapkan pemikiran dalam kehidupan tentang suatu yang tidak terduga. Ungkapan dari sesuatu kejadian yang tidak terduga ataupun ungkapan dari suatu hal yang didapatkan secara tidak terduga yang tidak pernah dipikirkan sebelumnya akan terjadi atau didapatkan.

Keempat, Inu ga nishi mukya o wa higashi (犬が西向きや尾は東) yang artinya anjing menghadap ke barat ekornya menghadap ke timur. Dilihat dari makna denotasi, peribahasa inu ga nishi mukya o wa higashi (犬が西向きや尾は東) ini terbentuk dari kata inu (犬) memiliki arti anjing, kata nishi (西) memiliki arti barat, kata muki (向き) memiliki arti menghadap, kata $o$ (尾) memiliki arti ekor dan kata higashi (東) memiliki arti timur. Dapat dipahami bahwa menurut kata pembentuknya peribahasa ini memiliki makna denotasi anjing menghadap barat ekornya menghadap ke timur. Makna konotasi dari peribahasa inu ga nishi mukya o wa higashi (犬が西向きや尾は東) adalah sesuatu yang sudah pasti. Situasi penerapan peribahasa inu ga nishi mukya o wa higashi (犬が西向きゃ尾は東) ini dipakai saat seseorang ingin mengungkapkan kebenaran dan ingin menyampaikan suatu ajaran kehidupan. Biasanya untuk mengungkapkan dan menggambarkan bahwa informasi yang didapat serta disampaikan merupakan informasi umum yang kepastian dan kebenaran tidak diragukan lagi sehingga informasi tersebut tidak perlu diperdebatkan.

Kelima, inu ni rongo (犬に論語) yang artinya memberi teori dalam buku pada anjing. Dilihat dari makna denotasi, peribahasa inu ni rongo (犬に論語) ini terbentuk dari kata inu (犬) yang memiliki arti anjing dan kata rongo (論語) yang memiliki arti teori dalam buku. Dengan demikian berdasarkan kata pembentuknya peribahasa ini memiliki makna denotasi memberi teori dalam buku pada anjing. Makna konotasi dalam peribahasa inu ni rongo (犬に論語) adalah melakukan sesuatu yang sia-sia. Makna konotasi peribahasa ini dapat ditelusuri dari makna denotasinya dimana kecerdasan seekor anjing sekalipun tidak akan mampu memahami sebuah teori dalam buku karena memang diluar kemampuannya. Situasi penerapan peribahasa inu ni rongo (犬に論語) ini biasanya dipakai dalam menyampaikan kritik ataupun sindiran untuk orang yang tidak bisa menghargai pemberian dari orang lain. Ketika orang yang diberikan tidak mengerti nilainya yang justu akan mengabaikan pemberian dari orang dan menyia-nyiakannya.

Keenam, Inu wa mikka kaeba san'nen on o wasurenu (犬は三日飼えば三年恩を忘れぬ) yang artinya memberi makan anjing tiga hari maka ia tidak akan melupakannya selama tiga tahun. Dilihat dari makna denotasi, peribahasa inu wa mikka kaeba sannen on o wasurenu (犬は三日飼えば三年恩を忘れぬ) ini terbentuk dari kata inu (犬) yang memiliki arti anjing, kata mikka (三日) yang memiliki arti 3 hari, kata kae (飼え) yang merupakan kata peribahasa 
yang memiliki arti sama dengan kata kau (飼う) yang berarti memelihara, kata san'nen (三年) yang memiliki arti tiga tahun, kata on (恩) yang memiliki arti kebaikan dan kata wasurenu (忘れぬ) yang merupakan kata yang memilki arti sama dengan kata wasurenai (忘れない) yang berarti tidak akan melupakan. Di sini dapat dipahami bahwa menurut kata pembentuknya peribahasa ini memiliki makna denotasi memberi makan anjing 3 hari maka ia tidak akan melupakannya selama 3 tahun. Pengunaan kata anjing pada makna denotasi ini karena anjing adalah sosok hewan sangat peka terhadap perasaan. Makna konotasi dalam peribahasa inu wa mikka kaeba san'nen on o wasurenu (犬は三日飼えば三年恩を忘れぬ) adalah setitik kebaikan yang tidak akan dilupakan. Situasi penerapan peribahasa inu wa mikka kaeba san'nen on o wasurenu (犬は三日飼えば三年恩を忘れぬ) ini seringkali dipakai untuk menyampaikan ajaran kehidupan tentang saling menolong. Peribahasa ini diungkapkan untuk mengingatkan ajaran kehidupan dan mengingatkan agar tidak pernah melupakan kebaikan dari orang lain yang pernah membantu disaat kita susah dan membalasnya jika kita mendapat kesempatan yang sama.

Ketujuh, Ken'en no naka (犬猿の仲) yang artinya bagai anjing dan monyet. Dilihat dari makna denotasi, peribahasa ken'en no naka (犬猿の仲) ini terbentuk dari kata ken (犬) yang memiliki arti anjing, kata en (猿) yang memiliki arti monyet dan kata naka (仲) memiliki arti hubungan. Dapat dipahami bahwa menurut kata pembentuknya peribahasa ini memiliki makna denotasi hubungan anjing dan monyet. Penggunaan kata anjing pada makna denotasi karena dari sudut pandang alam dan budaya masyarakat Jepang sudah tertanam bahwa sifat dan memiliki tugas yang berbeda dari kehidupan anjing dengan monyet itu sendiri. Peribahasa ini hampir sama dengan istilah anjing dan kucing yang seringkali dipakai untuk mengungkapkan sesuatu yang tidak akur karena walaupun hidup berdampingan tetapi merupakan jenis hewan yang berbeda dan sifat serta kebiasaan yang tidak bisa disatukan. Makna konotasi dari peribahasa ken'en no naka (犬猿の仲) adalah hubungan yang tidak akan bisa akur. Bagi masyarakat Jepang istilah monyet dan anjing jelas memiliki sifat yang berlawanan dan perselisihan diantara keduanya. Situasi penerapan peribahasa ken'en no naka (犬猿の仲) ini biasanya dipakai untuk menyindir atau mengkritik orang selalu memiliki perselisihan pendapat dan tidak mau mengalah satu sama lain yang mengakibatkan selalu timbul perselisihan yang tidak ada dapat diakhiri dengan musyawarah. Ungkapan peribahasa ini merupakan sindiran halus agar perselishan tidak diteruskan karena dapat merugikan kedua belah pihak.

Kedelapan, ken'ba no yashinai (犬馬の養い) yang artinya bagai memelihara anjing dan kuda. Dilihat dari makna denotasi, peribahasa ken'ba no yashinai (犬馬の養い) ini terbentuk dari kata ken (犬) yang memiliki arti anjing, kata ba (馬) yang memiliki arti kuda, dan kata yashinai (養い) yang memiliki arti memberi makan atau memelihara. Dapat dipahami bahwa menurut kata pembentuknya peribahasa ini memiliki makna denotasi memelihara anjing dan kuda. Pemilihan kata anjing dan kuda dalam peribahasa ini karena di Jepang anjing dan kuda dianggap hewan yang setia. Makna konotasi dalam peribahasa ken'ba no yashinai (犬馬の養い) adalah mengasuh seseorang tanpa perasaan. Dapat disimpulkan bahwa peribahasa ini makna konotasinya dapat ditelusuri dari makna denotasinya. Di Jepang hanya memenuhi kebutuhan seseorang tanpa menjalin komunikasi hubungan yang baik dan harmonis dianggap seperti memelihara anjing dan kuda yang hanya perlu makan untuk tetap hidup berdampingan dengan kita tanpa memerlukan perhatian lebih. Situasi penerapan peribahasa ken'ba no yashinai (犬馬の養い) ini biasanya dipakai untuk mengungkapkan perumpamaan yang menarik tentang kehidupan seseorang dan mengibaratkannya. Segala yang dilakukan harus dengan perasaan agar orang dalam hidup kita akan merasa bahagia dengan jika mendapat perhatian secara tulus sehingga akan tercapai keharmonisan dalam hidup.

Kesembilan, Inu mo kuwanai (犬も食わない) yang artinya bahkan anjing pun tidak akan memakannya. Dilihat dari makna denotasi, peribahasa inu mo kuwanai (犬も食わない) ini terbentuk dari kata inu (犬) memiliki arti anjing dan kata kuwanai (食わない) yang merupakan kata peribahasa yang memiliki arti sama dengan kata tabenai (食べない) memiliki arti tidak memakannya. Dapat dipahami bahwa menurut kata pembentuknya peribahasa ini memiliki 
makna denotasi bahkan anjing pun tidak akan memakannya. Alasan pemilihan anjing dalam peribahasa ini karena anjing dikenal sebagai hewan pemakan segala karena mampu menjadi karnivora dan omnivora disaat yang bersamaan. Makna konotasi dalam peribahasa inu mo kuwanai (犬も食わない) adalah tidak ingin ikut campur urusan orang lain. Dalam peribahasa ini anjing yang dikenal rakus dan memakan segala diibaratkan tidak mau memakannya dan mengibaratkan ketidak ikutsertaan dan menganggap itu bukan makananya. Situasi penerapan peribahasa inu mo kuwanai (犬も食わない) ini biasanya dipakai untuk menunjukan pemikiran dan pengetahuan tentang kehidupan. Peribahasa ini diungkapkan untuk memberitahukan seseorang agar menjadi seorang yang tau diri, memposisikan diri untuk tidak mencampuri urusan orang lain. Karena pemahaman kita tidak selamanya sesuai dengan pemahaman orang lain dan akan selalu memiliki pandangan yang berbeda-beda setiap individu.

Kesepuluh, O o furu inu wa tatakarezu (尾を振る犬は吒かれず) yang artinya anjing yang mengibaskan ekornya tidak dipukuli. Dilihat dari makna denotasi, peribahasa o o furu inu wa tatakarezu (尾を振る犬は吒かれず) ini terbentuk dari kata kata o (尾) yang memiliki arti ekor, kata furu (振る) yang memiliki arti mengibaskan, kata inu (犬) yang memiliki arti anjing dan kata tatakau (吒かう) yang memiliki arti dipukul. Dapat dipahami bahwa menurut kata pembentuknya peribahasa ini memiliki makna denotasi anjing yang mengibaskan ekornya tidak akan dipukuli. Anjing dipilih dalam peribahasa ini karena anjing dianggap hewan yang paling ekspresif diantara hewan peliharaan lain yang memiliki kedekatan dengan kehidupan manusia secara umum seperti ayam ataupun kucing. Makna konotasi dalam peribahasa 00 furu inu wa tatakarezu (尾を振る犬は吅かれず) adalah orang yang baik akan dicintai oleh semua orang. Anjing yang mengibaskan ekornya tidak akan dipukuli. Situasi penerapan peribahasa o o furu inu wa tatakarezu (尾を振る犬は吒かれず) ini seringkali untuk menyampaikan pemikiran tentang kehidupan. Pengungkapan peribahasa ini bertujuan agar dapat berbuat sesuai dengan perlakuan apa yang ingin kita dapatkan. Menunjukkan sikap menghargai sebelum kita ingin dihargai karena apapun perlakuan yang kita dapatkan dari orang lain merupakan cerminan perlakuan kita sendiri. Perbuatan baik akan mendapatkan balasan baik begitu juga sebaliknya perlakuan buruk akan mendapatkan balasan perbuatan buruk.

Kesebelas, ken'ba no kokoro (犬馬の心) yang artinya bagai perasaan anjing dan kuda. Dilihat dari makna denotasi, peribahasa kenba no kokoro (犬馬の心) ini terbentuk dari kata ken (犬) yang memiliki arti anjing, kata ba (馬) yang memiliki arti kuda, dan kata kokoro (心) yang memiliki arti perasaan. Disini dapat dipahami bahwa menurut kata pembentuknya peribahasa ini memiliki makna denotasi bagai perasaan anjing dan kuda. Alasan pemilihan anjing disini karena dalam kehidupan masyarakat Jepang, anjing dan kuda merupakan hewan yang setia dan menguntungkan dalam kelangsungan hidup manusia. Makna konotasi dari peribahasa ken'ba no kokoro (犬馬の心) adalah kesetiaan dengan kepercayaan dan rasa hormat. Dalam peribahasa ini menggambarkan seseorang yang memiliki kesetiaan dan kepercayaan dengan rasa hormat dalam bertugas serta mengerjakan tugas dengan sepenuh hati. Situasi penerapan peribahasa ken'ba no kokoro (犬馬の心) ini biasanya dipakai untuk mengibaratkan sesuatu yang menarik dalam kehidupan. Peribahasa ini diungkapkan agar memiliki rasa tulus ikhlas dalam segalah hal terutama di bidang pekerjaan. Tidak terpengaruh perlakuan orang di sekitar dan terus berbuat yang terbaik dalam hidup ini.

Kedua belas, Ken'ba no rou (犬馬の労) yang artinya bekerja bagai anjing dan kuda. Dilihat dari makna denotasi, peribahasa ken’ba no rou (犬馬の労) memiliki makna denotasi bekerja bagai anjing dan kuda. Makna denotasi masing-masing pembentuknya terbentuk dari kata ken (犬) yang memiliki arti anjing, kata ba (馬) yang memiliki arti kuda, dan kata rou (労) memiliki arti bekerja. Dapat dipahami bahwa menurut kata pembentuknya peribahasa ini memiliki makna denotasi bekerja bagai anjing dan kuda. Alasan pemilihan anjing dalam peribahasa ini karena di Jepang, selain sebagai hewan peliharaan, anjing dan kuda juga merupakan hewan yang dimanfaatkan tenaganya untuk membantu pekerjaan manusia. Makna konotasi dari peribahasa ken'ba no rou (犬馬の労) adalah mengabdi dengan tulus dan rendah hati. Makna konotasinya menjelaskan bahwa peribahasa ini digunakan saat seseorang bekerja dengan giat dan tulus tidak peduli dengan imbalan yang didapat dan 
berusaha menyelesaikan pekerjaan dengan sebaik mungkin. Situasi penerapan peribahasa ken'ba no rou (犬馬の労) ini kiasan yang menarik tentang suatu hal yang diumpamakan. Peribahasa dipakai agar kita tetap rendah hati dan melakukan pekerjaan kita secara professional tanpa harus memperhitungkan imbalan atau nominal yang akan didapatkan.

Ketiga belas, Hoeru inu wa kamitsukanu (吠える犬は噛み付かぬ) yang artinya anjing menggonggong tidak akan menggigit. Dilihat dari makna denotasi, peribahasa hoeru inu wa kamitsukanu (吠える犬は噛み付かぬ) ini terbentuk dari kata hoeru (吠える) yang berarti mengonggong, kata inu (犬) yang berarti anjing dan kata kamitsukane (噛み付かね) yang merupakan kata peribahasa yang memiliki arti sama dengan kata kamitsukanai (噛み付かない) yang berarti tidak mengigit. Dapat dipahami bahwa menurut kata pembentuknya ini memiliki makna denotasi anjing menggonggong tidak akan menggigit. Alasan pemilihan anjing pada peribahasa ini karena dilihat dari kebiasaan masyarakat pada umumnya termasuk Jepang yang bertujuan memelihara anjing untuk menjaga rumah dan melindungi rumah dari hewan lain maupun orang asing yang mendekati rumah. Makna konotasi dalam peribahasa hoeru inu wa kamitsukanu ( 吠える犬は噛み付かぬ) adalah banyak bicara tidak ada kemampuan. Anjing yang menggonggong tidak berarti akan langsung menggigit karena di Jepang anjing pada umumnya dipelihara tidak dilatih untuk menyerang secara langsung sehingga anjing yang menggongong tidak dianggap menggigit dan mengibaratkan tampilan yang ditemui belum tentu sama dengan sifat aslinya. Situasi penerapan peribahasa hoeru inu wa kamitsukanu ( 吠える犬は噛み付かぬ) ini seringkali diungkapkan untuk mengkritik ataupun memberi sindiran secara halus. Peribahasa ini diungkapkan agar memberikan kritik pada orang yang terlalu banyak bicara dan seakan merasa paling hebat tapi ternyata justru menunjukan kelemahannya sendiri.

Keempat belas, Bon'nō no inu wa oe domo sarazu (煩悩の犬は追えども去らず) yang artinya anjing yang rakus tidak akan pergi. Dilihat dari makna denotasi, peribahasa bon'nō no inu wa oe domo sarazu (煩悩の犬は追えども去らず) ini terbentuk dari kata bon'nou (煩悩) memiliki arti keinginan kerakusan, kata inu (犬) memiliki arti anjing, kata oe domo (追えども) memiliki arti mengikuti dan kata sarazu (去らず) memiliki arti pergi. Dapat dipahami bahwa menurut kata pembentuknya peribahasa ini memiliki makna denotasi anjing yang rakus tidak akan pergi. Anjing dipilih dalam peribahasa ini karena seekor anjing ketika makanan melimpah, anjing tersebut tidak akan pergi walaupun sudah merasa kenyang dan tidak mampu menghabiskan makanan yang berlebih tersebut. Makna konotasi dari peribahasa bon'nō no inu wa oe domo sarazu ( 煩悩の犬は追えども去らず) adalah hasrat yang tidak akan pernah puas. Makna konotasi dalam peribahasa ini dapat dilihat dari denotasi pembentuknya yaitu menggambarkan sifat orang yang tidak pernah merasa puas dan tidak pernah bersyukur atas apa yang didapatkan. Situasi penerapan peribahasa bon'nō no inu wa oe domo sarazu ( 煩悩の犬は追えども去らず) ini biasanya dipakai untuk mengkritik orang yang memiliki rasa serakah. Peribahasa ini diungkapkan untuk menyampaikan kritikan pada orang yang tidak pernah merasa puas akan apa yang didapat.

Kelima belas, Fūfu genka wa inu mo kuwanai (夫婦喧嘩は犬も食わない) yang artinya pasangan suami istri bertengkar, anjing pun kelaparan. Dilihat dari makna denotasi, peribahasa fūfu genka wa inu mo kuwanai (夫婦喧嘩は犬も食わない) ini terbentuk dari kata fūfu (夫婦) memiliki arti pasangan suami istri, kata genka (喧嘩) memiliki arti pertengkaran, kata inu (犬) memiliki arti anjing dan kata kuwanai (食わない) yang merupakan kata peribahasa yang memiliki arti sama dengan kata tabenai (食べない) memiliki arti tidak memakan / kelaparan. Dapat dipahamai bahwa menurut kata pembentuknya peribahasa ini memiliki makna denotasi pasangan suami istri bertengkar, anjing pun kelaparan. Pemilihan anjing dalam peribahasa ini karena anjing bagi masyarakat Jepang dianggap hewan setia dan mengabdi dengan tulus sehingga seringkali dianggap sebagai anggota keluarga sendiri. Makna konotasi dari peribahasa füfu genka wa inu mo kuwanai (夫婦喧嘩は犬も食わない) bermakna jika atasannya bermasalah maka bawahanya pun juga akan terkena dampaknya. Dalam peribahasa ini anjing dianggap menggambarkan pihak yang tidak mendapatkan apaapa dan justru kelaparan karena menunggu usainya pertengkaran dari pasangan suami istri yang merupakan tuannya. Situasi penerapan dalam peribahasa fūfu genka wa inu mo 
kuwanai (夫婦喧嘩は犬も食わない) ini biasanya diungkapkan untuk mengungkapkan kebenaran dalam kehidupan yang sering terjadi. Peribahasa ini digunakan untuk menyampaikan kebenaran dari fenomena kehidupan yang sering terjadi yaitu dampak yang buruk yang diterima sebagai seorang yang di posisi bawahan yang terkena dampak buruk dari sesuatu yang dilakukan atasannya. Seorang karyawan yang terlantar karena bosnya bermasalah dan justru berdampak buruk bagi kehidupan karyawan yang tidak melakukan kesalahan dalam bekerja karena hidupnya yang selalu bergantung pada atasan di tempatnya bekerja.

Keenam belas, Ware o aisuru mono wa waga inu o mo aisu (我を愛する者は我が犬をも愛す) yang artinya bila mencintai saya maka cintai juga anjing saya. Dilihat dari makna denotasi, peribahasa ware o aisuru mono wa waga inu o mo aisu (我を愛する者は我が犬をも愛す) ini terbentuk dari kata ware (我) yang memiliki arti saya, kata inu (犬) yang artinya anjing, dan kata aisu (愛す) yang artinya cinta. Dapat dipahami dari kata pembentuknya peribahasa ini memiliki makna denotasi bila mencintai saya maka cintai juga anjing saya. Pemilihan anjing dalam peribahasa ini karena kedekatan orang Jepang dengan anjing itu sendiri yang beranggapan bawa anjing merupakan bagian dari keluarga sehingga secara umum di Jepang sangat jarang ditemukan anjing liar tanpa pemilik yang jelas. Makna konotasi dari peribahasa ware o aisuru mono wa waga inu o mo aisu (我を愛する者は我が犬をも愛す) adalah mencintai dan menerima seutuhnya. Anjing dianggap memiliki kedekatan khusus dalam kehidupan sehingga tidak bisa dipisahkan dengan tuannya. Hal ini dapat dianggap menggambarkan seseorang yang ingin diterima ataupun harapan dari seseorang yang ingin mendapatkan seseorang yang bisa mencintai serta menerima secara utuh berupa baik buruk sifat dan juga baik buruk keluarga yang dimiliki. Situasi penerapan peribahasa ware o aisuru mono wa waga inu o mo aisu (我を愛する者は我が犬をも愛す) ini seringkali dipakai untuk mengungkapkan sesuatu yang menarik dan mengibaratkanya dengan sesuatu yang sering ditemui. Peribahasa ini biasanya diungkapkan oleh seseorang yang mengharapkan ada orang yang mencintainya dan menerima segala kekuraangannya juga dan ingin diterima seutuhnya baik buruk dirinya maupun keluarga yang dimilikinya.

Selanjutnya, peribahasa Jepang yang mengandung unsur inu (anjing) diklasifikasi berdasarkan isi. Pengklasifikasian tersebut sebagai berikut.

Terdapat 2 data yang digolongkan ke dalam jinsei no oshie ya shinri o arawashita (menunjukkan kebenaran dan ajaran kehidupan manusia). Data tersebut yaitu inu ga nishi mukya o wa higashi (犬が西向きゃ尾は東) yang artinya anjing menghadap ke barat ekornya menghadap ke timur serta bermakna memberitahukan hal yang sudah pasti dan inu wa mikka kaeba san'nen'on o wasurenu (犬は三日飼えば三年恩を忘れぬ) yang artinya memberi makan anjing tiga hari maka ia tidak akan melupakannya selama tiga tahun serta bermakna setitik kebaikan yang tidak akan dilupakan.

Berikutnya terdapat 5 data yang digolongkan ke dalam seikatsu no chisiki ya chie o tataite wataru (menunjukan pemikiran dan pengetahuan tentang kehidupan). Data tersebut yaitu Kai inu ni te o kamareru (飼い犬に手を噛まれる) yang artinya digigit oleh anjing peliharaan bermakna dikhianati orang-orang yang kita percayai, inu mo arukeba, bou ni ataru (犬も歩けば、棒にあたる) yang artinya anjing pun saat berjalan bisa terkena pukulan tongkat bermakna mendapatkan bencana yang tidak terduga; Bermakna kalau berusaha pasti akan berhasil, inu mo kuwanai (犬も食わない) yang artinya bahkan anjing pun tidak akan memakannya bermakna takut mencampuri urusan orang lain. O o furu inu wa tatakarezu (尾を振る犬は吒かれず) yang artinya anjing yang mengibaskan ekornya tidak dipukuli bermakna orang yang baik akan dicintai oleh semua orang, dan Fūfu genka wa inu mo kuwanai (夫婦喧嘩は犬も食わない) yang artinya pasangan suami istri bertengkar, anjing pun kelaparan bermakna tidak ikut campur urusan keluarga orang lain.

Selanjutnya, terdapat 5 data yang dapat digolongkan ke dalam hito o hihan shitari hinikutari shita mono (isinya menyindir atau mengkritik orang). Data tersebut yaitu inu no tooboe (犬の遠吠え) yang artinya anjing melolong bermakna orang yang tidak berdaya, inu ni rongo (犬に論語) yang artinya memberi teori dalam buku pada anjing bermakna melakukan sesuatu yang sia-sia, ken'en no naka (犬猿の仲) yang artinya bagai anjing dan Jurnal Pendidikan Bahasa Jepang | 90 
monyet bermakna hubungan yang tidak akan bisa akur, hoeru inu wa kamitsukanu (吠える犬は噛み付かぬ) artinya anjing menggonggong tidak akan menggigit bermakna jangan menilai seseorang berdasarkan tampilannya saja, dan bon'nō no inu wa oe domo sarazu (煩悩の犬は追えども去らず) artinya anjing yang rakus tidak akan pergi bermakna hasrat yang tidak akan pernah puas.

Terakhir, terdapat 4 data yang dapat digolongkan ke dalam monogoro no yoosu omoshiroku tatoeta mono (perumpamaan atau kiasan yang menarik tentang keadaan suatu hal). Data tersebut yaitu yaitu ken'ba no yashinai (犬馬の養い) artinya bagai memelihara anjing dan kuda bermakna mengasuh seseorang tanpa perasaan, ken'ba no kokoro (犬馬の心) artinya bagai perasaan anjing dan kuda bermakna kepercayaan dan rasa hormat, ken'ba no rou (犬馬の労) artinya bekerja bagai anjing dan kuda berrmakna mengabdi dengan tulus, dan ware o aisuru mono wa waga inu o mo aisu (我を愛する者は我が犬をも愛す) artinya mereka yang mencintai saya juga mencintai anjing saya bermakna mencintai seseorang juga menerima baik buruknya.

\section{Simpulan dan Saran}

Berdasarkan hasil analisis terhadap 16 peribahasa Jepang yang mengandung unsur inu (anjing), maka dapat disimpulkan bahwa terdapat makna denotasi, makna konotasi, situasi penerapan, dan klasifikasi peribahasa berdasarkan isi. Anjing dalam peribahasa Jepang memiliki banyak makna. Anjing juga diibaratkan memiliki kemiripan dengan tingkah laku dan kehidupan manusia. Sesuai dengan konteks penerapan, dalam peribahasa Jepang anjing tidak selalu bermakna positif, tetapi ada juga yang bermakna negatif. Sebagai contoh peribahasa kai inu ni te o kamareru (飼い犬に手を噛まれる) yang memiliki makna denotasi digigit oleh anjing peliharaan. Makna konotasinya adalah makna dikhianati orang-orang yang kita percayai dan situasi penerapan peribahasa ini biasanya digunakan untuk memberikan pengetahuan tentang kehidupan. Orang lain yang kita percayai bisa saja berkhianat demi mendapatkan keuntungan bagi dirinya sendiri.

Menyadari masih banyak kekurangan pada penelitian ini, diharapkan bagi penelitian selanjutnya agar dapat mengkaji lebih dalam terutama tentang makna yang terdapat dalam kata anjing pada peribahasa Jepang berdasarkan latar belakang kebudayaan maupun kepercayaan masyarakat Jepang.

\section{Daftar Pustaka}

Chaer, Abdul. 2003. Psikolinguistik, Kajian Teoretik. Jakarta: PT Rineka Cipta.

Gifari, Ichsan. 2018. Interpretasi Makna Idiomatikal dan Leksikal Peribahasa Jepang yang Mengandung Unsur Kata Inu (Anjing). Semarang: Universitas Diponegoro.

Wasrie, Moh. Kusnadi. 2006. Kumpulan Peribahasa. Solo: Lingkar Media.

Vijjananda, Handaka. 2012. Hachiko. Jakarta: Awarenes Publishing.

Kumpulan Ungkapan Peribahasa Jepang. Tersedia pada https://proverb-encyclopedia.com/ (Diakses pada 2 agustus 2019) 